\title{
Exploring food, agricultural, and environmental law and policy reforms
}

\author{
Book review by Sheila Fleischhacker, National Institutes \\ of Health
}

\section{Food, Agriculture, and Environmental Law}

Angelo, M. J., Czarnezki J. J., \& Eubanks II, W. S. (2013). Food, agriculture, and environmental law. Washington, D.C.: Environmental Law Institute.

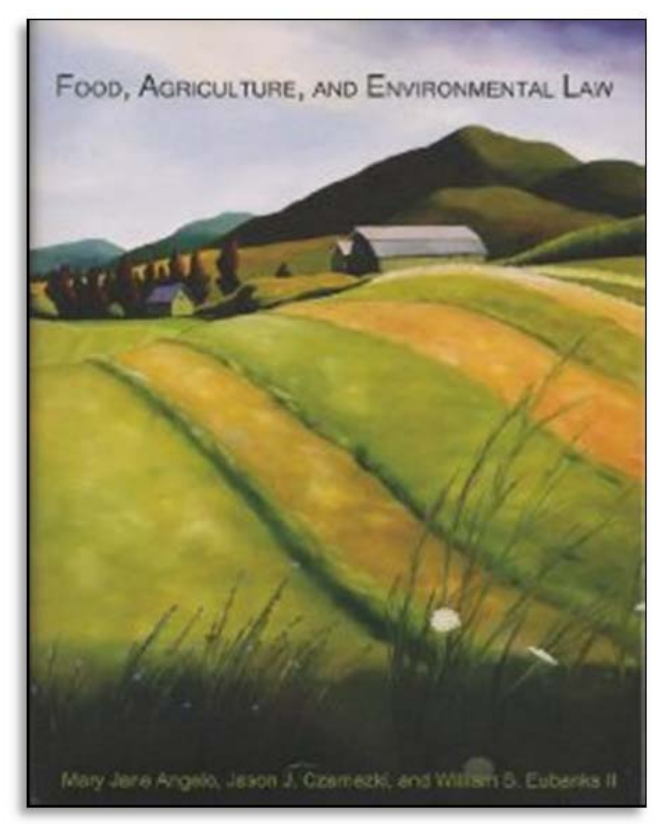

Published online February 10, 2014

Citation: Fleischhacker, S. (2014). Exploring food, agricultural, and environmental law and policy reforms [Book review of Food, Agriculture, and Environmental Law]. Journal of Agriculture, Food Systems, and Community Development, 4(2), 179-181. http://dx.doi.org/10.5304/jafscd.2014.042.003

Copyright (C) 2014 by New Leaf Associates, Inc.

B ooks have played an important role in shaping the United States' food, agricultural, and environmental systems. One of the most influential

Sheila Fleischhacker, $\mathrm{PhD}$, JD, is the senior public health and science policy advisor of the National Institutes of Health (NIH) Division of Nutrition Research Coordination, specializing in health disparities research and the role of environmental and policy strategies in chronic disease prevention and health promotion. Prior to joining NIH, Dr. Fleischhacker was an adjunct assistant professor of nutrition at the University of North Carolina at Chapel Hill and co-principal investigator of the American Indian Healthy Eating Project and its subsequent capacity-building project known as Healthy, Native North Carolinians (http://americanindianhealthyeating. unc.edu). She received a B.S. (2000) and J.D. (2007) with a Certificate in Health Law from Loyola University Chicago and Ph.D. in Integrative Biosciences/Nutritional Sciences from The Pennsylvania State University (2004). She was admitted into the Illinois Bar in November 2007. She can be reached at sheila.fleischhacker@,nih.gov. is a1906 book entitled The Jungle written by Upton Sinclair that used investigative reporting to descriptively portray the working and living conditions endured by immigrants working in American meatpacking factories. Sinclair horrified readers and stimulated public outrage that led to political pressure to enact the Meat Inspection Act and the Pure Food and Drug Act, as well as establish the U.S. Food and Drug Administration. Another influential book, Silent Spring (1962) by Rachel Carson, led to stronger pesticide regulations and launched the environmental movement. More recent examples include Fast Food Nation: The Dark Side of the All-American Meal by Eric Schlosser (2001) and a series of writings by Michael Pollen (e.g., The Botany of Desire: A Plant's-Eye View of the World (2001) and The Omnivore's Dilemma: A Natural History of Four Meals (2006)). Both authors raised 
awareness about the associations between an increasingly industrialized food supply and obesity.

These literary pieces provide unique, descriptive food systems insights; however, individually or collectively, they do not provide a systematic approach to understanding the complex and dynamic set of laws, regulations, policies, and procedures established under global, federal, tribal, state, and local authority governing our food, agricultural, and environmental systems. As advocacy mounts for various reforms and research advances our understanding of the multifaceted opportunities and challenges for our current and future food, agricultural, and environmental systems, a need exists for a transdisciplinary examination of the historical and contemporary legal and political developments influencing these systems.

In Food, Agriculture, and Environment Law, the editorial team of Mary Jane Angelo, Jason J. Czarnezki, and Williams S. Eubanks II coordinated more than 11 authors to examine a range of issues that were a part of past, present, and potentially future farm bills, as well as other influential global, federal, state, and local laws shaping food, agricultural, and environmental systems. Eighteen chapters tackle the policy and politics involved in the United States' evolving governing approach to ensuring safe, healthy, affordable, and sustainable food, agriculture, and environmental systems. One of the editors, William S. Eubanks II, starts the book by briefly explaining the history of U.S. agriculture and the emergence of the farm bill during the Great Depression, which he states was a "temporary fix to an urgent situation" for an economically depressed farming economy. His introduction provides facts and figures to illustrate declining trends in the number of farms and farmers in our country and the role of crop maximization in shaping American farm policy and rural America. Eubanks concludes by outlining the remaining chapters: components of the current farm bill (chapter 2); ecological impacts of modern farming (chapters 3-7), intersections between agriculture and existing environmental and related laws (chapters 8-13), and suggested reforms (chapters 14-18).

Chapter 2 sets the stage for the components of the current farm bill under debate, particularly key environmental provisions including farm commodity programs (Title I), conservation (Title II), energy (Title IX), and horticulture (Title X). The authors discuss how budget and trade constrain current and future farm bill considerations. Chapter 2, and the book as a whole, gave little attention to relevant domestic food and nutrition assistance components of the farm bill (Title IV), particularly the Supplemental Nutrition Assistance Program (SNAP), formerly known as food stamps. Estimated to serve more than 45 million lowincome individuals and families at a cost of about $\$ 80$ billion a year (in US dollars), SNAP is a significant component of the farm bill and has been a contentious issue contributing to disagreement between the House and Senate. Nonetheless, the book covers relevant modern environmental aspects relating to the farm bill using very detailed examinations of the environmental impacts of industrial fertilizers and pesticides (chapter 3), agricultural irrigation (chapter 4), animal agriculture (chapter 5), genetically modified organisms (chapter 6), and food production, processing, packaging, and distribution (chapter 7).

In addition to examining the farm bill, several chapters (e.g., chapters 8-13 and 16) analyze pertinent agriculture and environment laws. For instance, chapter 8 points out shortcomings of the Federal Insecticide, Fungicide, and Rodenticide Act, which grants the U.S. Environmental Protection Agency the authority to regulate pesticides. Chapter 9 specifically points to gaps in the Clean Water Act's permitting program; as one example, the Act does not cover the majority of agricultural discharges. Likewise, chapter 10 explores the federal, regional, and state monitoring and enforcement regulatory gaps relevant to agricultural air pollutants. Another law examined is the Endangered Species Act (chapter 11), which does not exempt agricultural activities. The authors, nevertheless, point out how proving causation during prosecution and enforcement has limited this Act's ability to curb problematic agricultural practices. Chapters 12 and 13 cover a variety of food statutes including the Food Safety Modernization Act of 2010 and certain provisions of the Healthy, Hunger-Free Kids Act of 2010 that strive to 
promote locally grown and raised foods. There is not much attention given to land use and zoning laws that aim to promote community gardens, farmers' markets, or mobile vending, nor to policies and programs incentivizing retail food outlets in underserved communities. Chapter 14, as one of the few exceptions, discusses the pros and cons of zoning agricultural use districts.

The concluding chapters generally suggest incremental but steady changes, recognizing budgetary and political constraints of major reforms. These changes include rewarding farmers for implementing sound ecological practices and providing nutritious products for consumers, and supporting research that more effectively examines the intersections between food, agriculture, and the environment. Other suggested reforms include exploring how dietary guidelines and food labeling can be mobilized to promote nutritious foods produced through sustainable agriculture practices. Throughout the book, the authors consistently emphasize the importance of creating comprehensive strategies and recommend that readers consider the individual approaches put forth in combination - not as isolated solutions - to developing more sustainable food, agricultural, and environmental systems.
Taken together, the 18 chapters tackle complex and dynamic food, agricultural, and environmental governing structures, providing both historical and contemporary illustrations. Several potential levers for reducing the environmental impacts of food and agricultural practices are examined and a number of short- and long-term reforms are explored in a style that is understandable and actionable for practitioners in the field. The book (or chapters of it) will likely be a useful tool for food, agricultural, and environmental law and policy courses, workshops, or professional or personal development pursuits. A stronger, more consistent editorial presence in future editions or an instructor's manual might facilitate meaningful classroom or book club discussions. Some curriculum-friendly examples could include discussing how the chapters work together; helping to compare and contrast viewpoints presented and, as needed, inserting conflicting views when not covered by the book; and supplementing a chapter(s) to provide additional historical and contemporary context with books such as The Jungle, media, reports, peer-reviewed research, or legislation including the long-awaited farm bill (Agriculture Act of 2014 signed into law by President Obama on February 7, 2014). 